\title{
Cell size of various lactic acid bacteria as determined by scanning electron microscope and image analysis
}

\section{Athanasios Kokkinos ${ }^{\mathrm{a} *}$, Constantinos Fasseas ${ }^{\mathrm{b}}$, Elias Eliopoulos ${ }^{\mathrm{c}}$, George Kalantzopoulos ${ }^{\mathrm{a}}$}

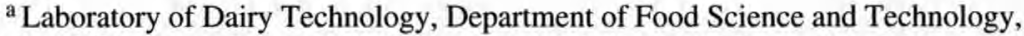 \\ ${ }^{b}$ Electron Microscopy Laboratory, Department of Agricultural Biology and Biotechnology, \\ ${ }^{\mathrm{c}}$ Genetics Laboratory, Department of Agricultural Biology and Biotechnology, \\ Agricultural University of Athens, Iera odos 75, 11855 Athens, Greece
}

(Received 25 November 1996; accepted 6 April 1998)

\begin{abstract}
Cells from 48 pure lactic acid bacterial strains from the ACA-DC collection were studied under the scanning electron microscope (SEM) and the images were photographed and processed with an Image Analysis software. The diameters of several cocci and the lengths and widths of several lactobacilli strains were measured, then the size parameters were statistically analyzed by variance analysis. Significant differences were found between the cell sizes of the cocci strains (Streptococcus 1.07 to $1.21 \mu \mathrm{m}$, Enterococcus 0.87 to $1.01 \mu \mathrm{m}$, Lactococcus 0.75 to $0.95 \mu \mathrm{m}$ ), but not between lengths and widths of the bacilli strains because too high variations were found in the last measurements. (C) Inra/Elsevier, Paris.
\end{abstract}

lactic acid bacteria / bacterial cell / SEM / image analysis / cell size

Résumé - Étude granulométrique des cellules de bactéries lactiques par microscopie électronique à balayage associée à l'analyse d'images. Des cellules de 48 souches pures de bactéries lactiques de la collection ACA-DC ont été étudiées par microscopie électronique à balayage (MEB). Les photographies obtenues ont été scannées puis analysées à l'aide de l'analyseur d'images Sigmascan. Les diamètres des cocci ainsi que les longueurs et largeurs des lactobacilles ont été mesurés. L'analyse des variances montre des différences caractéristiques entre les différents genres de cocci (Streptococcus de 1,07 à $1,21 \mu \mathrm{m}$, Enterococcus de 0,87 à $1,01 \mu \mathrm{m}$, Lactococcus de 0,75 à $0,95 \mu \mathrm{m})$. En revanche, dans les conditions expérimentales utilisées, il n'a pas été possible de montrer de différences significatives entre les genres de lactobacilles. (C) Inra/Elsevier, Paris.

bactérie lactique / cellule bactérienne / MEB / analyse d'image / taille de cellule

\footnotetext{
* Correspondence and reprints.
} 


\section{INTRODUCTION}

Bacterial cell size is still a useful morphological characteristic used in the classification and identification of bacteria. Morphology is easy to study and analyze, particularly in eucaryotic micro-organisms and the more complex procaryotes. In addition, morphological comparisons are valuable because structural features which depend on the expression of many genes, are usually genetically stable [16]. Thus, morphological similarity is a good indication of phylogenetic relatedness. Although the light microscope (LM) has always been a very important tool, its resolving power of about $0.2 \mu \mathrm{m}$ decreases its value in viewing smaller micro-organisms and structures. During the last decades the electron microscope has become a powerful tool in the examination of bacterial cells. The transmission electron microscope (TEM) is mainly now used by microbiologists for the study of the intracellular or cell wall structure [12], or for a quick examination of the bacterial cell with negative staining. The scanning electron microscope (SEM) is used for the study of the cell surface and its properties $[1,5,6,19]$ or in the greater field of food science and technology, usually for the structure analysis of food products [8] such as milk products [11, 13], cheese [3] meats, raisins, etc. Others have used the SEM for the observation of the microflora in some food products $[2,17]$. The SEM together with the LM, according to Zenseky et al. [20], is becoming increasingly more useful in imaging techniques for microbial study.

Moreover; image analysis, a new and developing technique, is now applicable in almost all sciences dealing with images in great detail. The major scope of the image analysis is to define parameters such as size, number, shape, position and optical density of the objects which are recognized in an image [7]. In collaboration with image processing that improves the image in viewing (e.g., zooming, sharpening, segmentation), it is becoming a powerful tool for scientists because of its great accuracy, repetition and fidelity.

The aim of this work was to determine whether the small differences in cell sizes of the lactic acid bacteria (LAB) we observed with the LM were real and stable and could be used for their identification and classification.

The most commonly employed method for measuring bacteria is by means of an ocular micrometer. Measurements can also be made by using a camera lucid attachment and drawing oculars, or by projecting the real image on a screen and measuring the bacteria. In this work, an effort was made to use image analysis techniques. Since these techniques require well-defined images, SEM visualization was considered the most appropriate because it gives highly magnified, well-focused, high resolution images.

\section{MATERIALS AND METHODS}

A total of 48 strains of LAB from the ACADC collection of the Laboratory of Dairy Technology of the Agricultural University of Athens, all isolated from traditional Greek products, were examined. The number of strains from each species and their collection code is shown on table 1 .

\subsection{Growth conditions}

All the strains were in the form of pure frozen cultures and were subcultured three times in growth media containing $10 \%$ skimmed milk powder supplemented with $0.2 \%$ yeast extract (Difco). The growth temperature was $37^{\circ} \mathrm{C}$ for all strains except those of the Lactococcus lactis subsp lactis which were incubated at $30^{\circ} \mathrm{C}$. The inoculum amount was $3 \%$ for the Lactobacillus delbrueckii subsp bulgaricus strains and $2 \%$ for all the others. The incubation time was $6 \mathrm{~h}$ for the cocci strains and $8 \mathrm{~h}$ for the bacilli strains.

\subsection{Sample preparation for SEM}

After the third subculture, $0.5 \mathrm{~mL}$ were taken from the coagulated media and washed with 
Table I. Strains studied and their collection codes.

Tableau I. Souches étudiées avec leur code dans la collection.

Strain name

Streptococcus thermophilus

Lactococcus lactis subsp lactis

Enterococcus faecalis

Enterococcus faecium

Enterococcus durans

Lactobacillus delbrueckii subsp. bulgaricus
ACA-DC collection codes

\author{
$2,3,4,5,6,7,8,9,10,11,12,15$ \\ $47,48,49,50,51,52,53,54,55,56,57,58$ \\ $138,239,240,252$ \\ $165,174,241,225$ \\ $242,223,226,228$
}

$84,85,86,87,88,90,100,101,102,103,104,105$
$0.5 \mathrm{~mL}$ of phosphate buffer $\left(0.1 \mathrm{~mol} \cdot \mathrm{L}^{-1}, \mathrm{pH}\right.$ 7.2). After three washes, each was followed by a centrifugation ( $2000 \mathrm{rpm}, 10 \mathrm{~min}$ ), the cells were resuspended in $1 \mathrm{~mL}$ of the buffer. From that media a small amount (approximately $200 \mu \mathrm{L}$ ) was taken and mounted directly on aluminium SEM stubs without prior fixation, air dried at $40^{\circ} \mathrm{C}$ and sputter coated with gold. Preliminary experiments showed that fixation, dehydration and critical point drying offered no advantages to the preservation of the cells. The samples were then observed and photographed with a Cambridge Stereoscan S-150. Because the method relies on the accuracy of measurements, care was taken to always use the microscope at the same viewing angle.

\subsection{Scanner settings and image analysis}

To scan the received pictures we used the GT 9000 EPSON scanner model under the following settings:

gray levels: 64; sharpness: very sharp; brightness: normal; resolution $\mathrm{x}, \mathrm{y}$ : $663 \mathrm{dpi}$; graphic file type: bitmaps for Windows (.bmp).

For the image analysis of the micrographs we used the SigmaScan image software (Jandel Scientific, San Rafael, CA, USA). The analysis was limited in measuring the diameters of the cocci cells and the widths and lengths of the bacilli cells. After calibrating the program according to the scale bar on the micrographs, cells were magnified for better definition of the cell edges; the cells were then measured by moving the pointer from one cell edge to the other. The program was keeping the measurements in memory and calculating some statistical values.

\section{RESULTS AND DISCUSSION}

Tables II, IV, VI, VII and VIII show the data and statistics obtained with the image analysis software. Each table is for one genus. Before any discussion we divided the means of each genus into classes, as shown on tables III, $V$ and $I X$ for better comparison. The class intervals in each of these tables were calculated using the model of Sturges where the class interval $(C)$ is given by the type $\mathrm{C}=\mathrm{R} / \mathrm{q}$ where $\mathrm{R}=$ Max value Min value and $q=1+3.32 \log _{10}(\mathrm{n})$ where $n$ is the number of measurements.

Beginning the interpretation of the results for each genus separately, we can see on tables II and III that all the Streptococcus thermophilus strains (figure 1a) have diameters apparently bigger than $1.00 \mu \mathrm{m}$ with the most common class interval between 1.07 and $1.21 \mu \mathrm{m}$. Eight out of the 12 strains are found in this class interval. According to [4] cells of the genus Streptococcus are smaller than $2 \mu \mathrm{m}$ in diameter while the Streptococcus thermophilus cells have a diameter between 0.7 to $0.9 \mu \mathrm{m}$, although these figures differ from our observations regarding cellular sizes. The Lactococcus lactis subsp lactis strains (figure $1 b$ ), as shown on tables $I V$ and $V$, are smaller than the Streptococcus thermophilus ones with a diameter of approximately 0.75 to $0.95 \mu \mathrm{m}$. According to Mundt [15], the Streptococcus lactis (known now as Lactococcus lactis) cells are 0.5 to $1.0 \mu \mathrm{m}$ in diameter which is similar to 
Table II. Statistical results for the cell diameter of Streptococcus thermophilus strains.

Tableau II. Résultats statistiques sur le diamètre cellulaire des souches de Streptococcus thermophilus.

\begin{tabular}{|c|c|c|c|c|c|c|c|c|c|}
\hline Strain code & $\begin{array}{l}\text { Diameter } \\
\bar{\chi}(\mu \mathrm{m})\end{array}$ & $\begin{array}{l}\text { Standard } \\
\text { deviation } \\
(\mu \mathrm{m})\end{array}$ & $\begin{array}{l}\text { Standard } \\
\text { error } \\
(\mu \mathrm{m})\end{array}$ & $\begin{array}{c}95 \% \\
\text { confidence } \\
\text { space }(\mu \mathrm{m})\end{array}$ & $\begin{array}{c}99 \% \\
\text { confidence } \\
\text { space }(\mu \mathrm{m})\end{array}$ & $\begin{array}{c}n \\
\text { (number of } \\
\text { cells measured) }\end{array}$ & $\sum_{1}^{n} \mathrm{x}(\mu \mathrm{m})$ & $\begin{array}{l}\text { Minimum } \\
\text { values } \\
(\mu \mathrm{m})\end{array}$ & $\begin{array}{l}\text { Maximum } \\
\text { values } \\
(\mu \mathrm{m})\end{array}$ \\
\hline 2 & 1.21 & 0.01 & 0.02 & 0.04 & 0.05 & 30 & 36.26 & 1.03 & 1.45 \\
\hline 3 & 1.18 & 0.04 & 0.007 & 0.02 & 0.02 & 32 & 37.64 & 1.08 & 1.26 \\
\hline 4 & 1.12 & 0.13 & 0.02 & 0.05 & 0.016 & 34 & 38.20 & 0.87 & 1.39 \\
\hline 5 & 1.06 & 0.15 & 0.03 & 0.06 & 0.09 & 24 & 25.36 & 0.84 & 1.49 \\
\hline 6 & 1.17 & 0.14 & 0.03 & 0.05 & 0.07 & 30 & 35.23 & 0.98 & 1.44 \\
\hline 7 & 1.32 & 0.17 & 0.03 & 0.06 & 0.08 & 30 & 39.63 & 1.04 & 1.65 \\
\hline 8 & 1.19 & 0.15 & 0.03 & 0.06 & 0.07 & 29 & 34.39 & 0.88 & 1.49 \\
\hline 9 & 1.17 & 0.1 & 0.02 & 0.03 & 0.04 & 40 & 46.92 & 0.94 & 1.34 \\
\hline 10 & 1.13 & 0.09 & 0.02 & 0.03 & 0.05 & 23 & 31.74 & 0.93 & 1.33 \\
\hline 11 & 1.14 & 0.11 & 0.02 & 0.04 & 0.05 & 33 & 37.73 & 0.97 & 1.39 \\
\hline 12 & 1.02 & 0.1 & 0.02 & 0.04 & 0.05 & 29 & 29.66 & 0.83 & 1.23 \\
\hline 15 & 1.23 & 0.01 & 0.02 & 0.04 & 0.05 & 30 & 37.05 & 1 & 1.42 \\
\hline
\end{tabular}

Table III. Classification into groups of the Streptococcus thermophilus strains according to the mean of their cell diameter. Tableau III. Classification des souches de Streptococcus thermophilus en groupes suivant leur diamètre cellulaire moyen.

\begin{tabular}{cc}
\hline Groups (in $\mu \mathrm{m})$ & Strains \\
\hline $1.00-1.07$ & 5,12 \\
$1.07-1.14$ & $4,10,11$ \\
$1.14-1.21$ & $2,3,6,8,9$ \\
$1.21-1.28$ & 15 \\
$1.28-1.35$ & 7 \\
\hline
\end{tabular}


Table IV. Statistical results for the cell diameter of Lactococcus lactis subsp. lactis strains.

Tableau IV. Résultats statistiques sur le diamètre cellulaire des souches de Lactococccus lactis subsp. lactis.

\begin{tabular}{|c|c|c|c|c|c|c|c|c|c|}
\hline Strain code & $\frac{\text { Diameter }}{\bar{\chi}(\mu \mathrm{m})}$ & $\begin{array}{c}\text { Standard } \\
\text { deviation } \\
(\mu \mathrm{m})\end{array}$ & $\begin{array}{l}\text { Standard } \\
\text { error } \\
(\mu \mathrm{m})\end{array}$ & $\begin{array}{c}95 \% \\
\text { confidence } \\
\text { space }(\mu \mathrm{m})\end{array}$ & $\begin{array}{c}99 \% \\
\text { confidence } \\
\text { space }(\mu \mathrm{m})\end{array}$ & $\begin{array}{c}n \\
\text { (number of } \\
\text { cells measured) }\end{array}$ & $\sum_{1}^{n} \mathrm{x}(\mu \mathrm{m})$ & $\begin{array}{l}\text { Minimum } \\
\text { values } \\
(\mu \mathrm{m})\end{array}$ & $\begin{array}{l}\text { Maximum } \\
\text { values } \\
(\mu \mathrm{m})\end{array}$ \\
\hline 47 & 0.83 & 0.06 & 0.01 & 0.02 & 0.03 & 34 & 28.29 & 0.72 & 0.98 \\
\hline 48 & 0.84 & 0.06 & 0.01 & 0.02 & 0.03 & 29 & 24.4 & 0.69 & 0.97 \\
\hline 49 & 0.81 & 0.14 & 0.03 & 0.06 & 0.08 & 26 & 21.06 & 0.57 & 1.07 \\
\hline 50 & 0.85 & 0.1 & 0.02 & 0.04 & 0.06 & 24 & 20.42 & 0.69 & 1.14 \\
\hline 51 & 0.77 & 0.06 & 0.01 & 0.03 & 0.04 & 21 & 16.12 & 0.65 & 0.86 \\
\hline 52 & 0.95 & 0.16 & 0.04 & 0.07 & 0.1 & 20 & 18.95 & 0.66 & 1.15 \\
\hline 53 & 0.81 & 0.08 & 0.02 & 0.03 & 0.04 & 29 & 23.53 & 0.59 & 0.99 \\
\hline 54 & 0.82 & 0.08 & 0.01 & 0.03 & 0.04 & 27 & 22.26 & 0.73 & 1.06 \\
\hline 55 & 0.86 & 0.07 & 0.02 & 0.03 & 0.04 & 23 & 19.72 & 0.71 & 0.99 \\
\hline 56 & 0.81 & 0.06 & 0.01 & 0.03 & 0.04 & 26 & 21.08 & 0.7 & 0.98 \\
\hline 57 & 0.82 & 0.08 & 0.02 & 0.04 & 0.05 & 20 & 16.47 & 0.68 & 0.99 \\
\hline 58 & 1.17 & 0.07 & 0.02 & 0.03 & 0.04 & 20 & 23.37 & 1.04 & 1.33 \\
\hline
\end{tabular}

Table V. Classification into groups of the Lactococcus lactis subsp. lactis strains according to the mean of their cell diameter. Tableau V. Classification des souches de Lactococcus lactis subsp. lactis en groupes suivant leur diamètre cellulaire moyen.

\begin{tabular}{cc}
\hline Groups $($ in $\mu \mathrm{m})$ & Strains \\
\hline $0.75-0.84$ & $47,48,49,51,53,54,56,57$ \\
$0.84-0.93$ & 50,55 \\
$0.93-1.02$ & 52 \\
$1.02-1.11$ & - \\
$1.11-1.2$ & 58 \\
\hline
\end{tabular}


Table VI. Statistical results for the cell diameter of Enterococcus faecalis strains.

Tableau VI. Résultats statistiques sur le diamètre cellulaire des souches d'Enterococcus faecalis.

\begin{tabular}{lcllcccccc}
\hline Strain code & $\begin{array}{c}\text { Diameter } \\
\bar{\chi}(\mu \mathrm{m})\end{array}$ & $\begin{array}{c}\text { Standard } \\
\text { deviation } \\
(\mu \mathrm{m})\end{array}$ & $\begin{array}{c}\text { Standard } \\
\text { error } \\
(\mu \mathrm{m})\end{array}$ & $\begin{array}{c}95 \% \\
\text { confidence } \\
\text { space }(\mu \mathrm{m})\end{array}$ & $\begin{array}{c}99 \% \\
\text { confidence } \\
\text { space }(\mu \mathrm{m})\end{array}$ & $\begin{array}{c}n \\
\text { cells measured })\end{array}$ & $\begin{array}{c}\sum_{1}^{n} \times(\mu \mathrm{m}) \\
1\end{array}$ & $\begin{array}{c}\text { Minimum } \\
\text { values } \\
(\mu \mathrm{m})\end{array}$ & $\begin{array}{c}\text { Maximum } \\
\text { values } \\
(\mu \mathrm{m})\end{array}$ \\
\hline 138 & 0.84 & 0.09 & 0.02 & 0.04 & 0.06 & 19 & 15.94 & 0.69 \\
239 & 0.9 & 008 & 0.02 & 0.04 & 0.05 & 22 & 19.87 & 0.79 \\
240 & 0.88 & 0.08 & 0.02 & 0.04 & 0.05 & 21 & 18.5 & 0.72 \\
252 & 1.14 & 0.08 & 0.02 & 0.03 & 0.04 & 24 & 27.31 & 0.96 \\
\hline
\end{tabular}

Table VII. Statistical results for the cell diameter of Enterococcus faecium strains.

Tableau VII. Résultats statistiques sur le diamètre cellulaire des souches d'Enterococcus faecium.

\begin{tabular}{llllcccccc}
\hline Strain code & $\begin{array}{l}\text { Diameter } \\
\bar{\chi}(\mu \mathrm{m})\end{array}$ & $\begin{array}{c}\text { Standard } \\
\text { deviation } \\
(\mu \mathrm{m})\end{array}$ & $\begin{array}{c}\text { Standard } \\
\text { error } \\
(\mu \mathrm{m})\end{array}$ & $\begin{array}{c}95 \% \\
\text { confidence } \\
\text { space }(\mu \mathrm{m})\end{array}$ & $\begin{array}{c}99 \% \\
\text { confidence } \\
\text { space }(\mu \mathrm{m})\end{array}$ & $\begin{array}{c}n \\
\text { (number of } \\
\text { cells measured })\end{array}$ & $\begin{array}{c}\sum_{1}^{n} \mathrm{x}(\mu \mathrm{m}) \\
1\end{array}$ & $\begin{array}{c}\text { Minimum } \\
\text { values } \\
(\mu \mathrm{m})\end{array}$ & $\begin{array}{c}\text { Maximum } \\
\text { values } \\
(\mu \mathrm{m})\end{array}$ \\
\hline 165 & 0.92 & 0.01 & 0.02 & 0.04 & 0.06 & 23 & 21.26 & 0.74 \\
174 & 0.98 & 0.1 & 0.02 & 0.05 & 0.06 & 23 & 22.5 & 0.78 & 1.1 \\
241 & 0.92 & 0.07 & 0.01 & 0.03 & 0.04 & 24 & 22.04 & 0.81 \\
225 & 0.84 & 0.12 & 0.02 & 0.05 & 0.07 & 24 & 20.04 & 0.62 & 1.04 \\
\hline
\end{tabular}




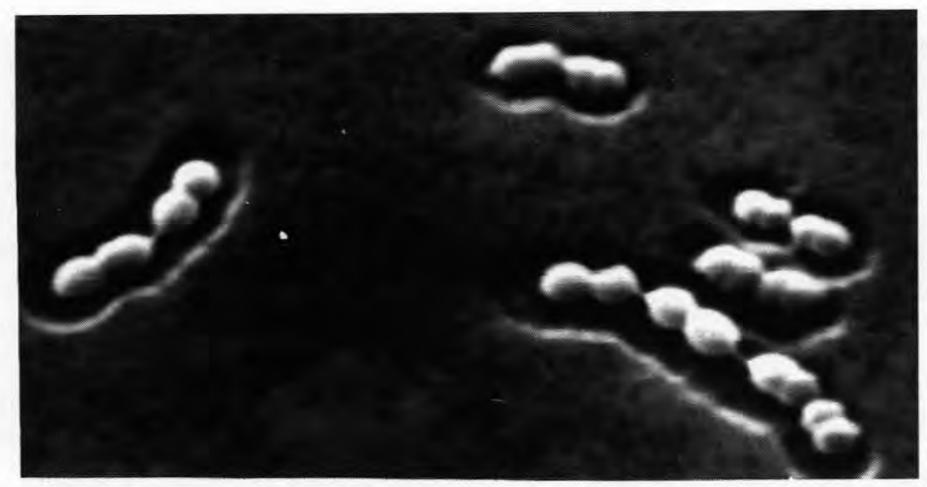

a. Streptococcus thermophilus ACA-DC 9 $(\mathrm{x} 4000)$
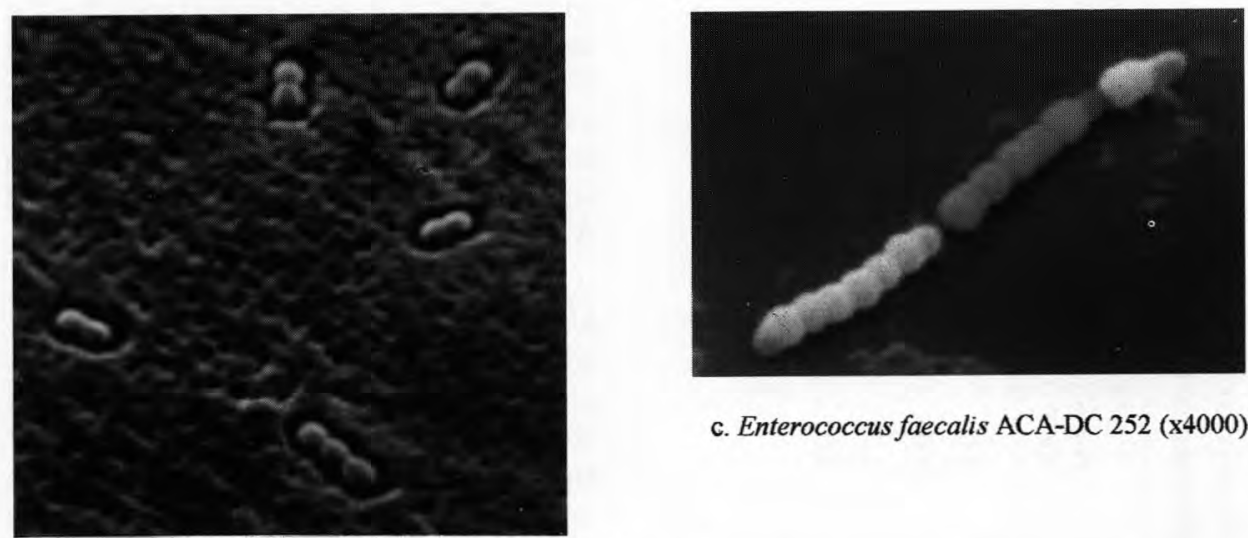

c. Enterococcus faecalis ACA-DC 252 (x4000)

b. Lactococcus lactis subsp lactis ACA-DC 53 (x4000)
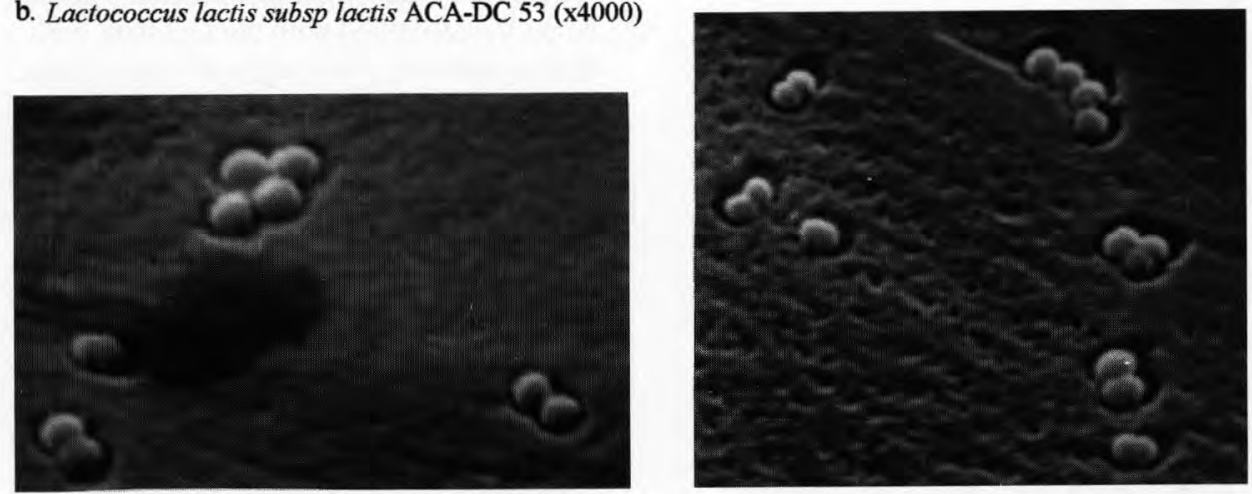

d. Enterococcus faecium ACA-DC 174 ( $\mathrm{x} 4000)$

e. Enterococcus durans ACA-DC 226 (x4000)

Figure 1a-e. Pictures of the cocci genera studied as received from SEM.

Figure 1a-e. Photographies des genres de cocci étudiés obtenues par MEB. 


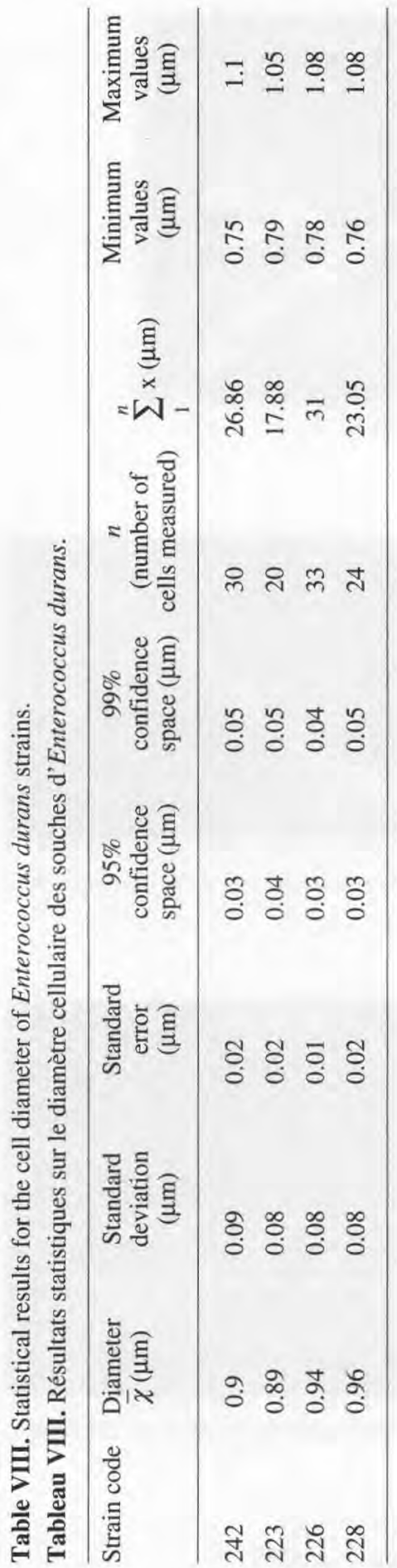

what we found. The strain ACA-DC 58 is bigger in diameter than the other Lactococcus lactis subsp lactis strains $(1.17 \mu \mathrm{m})$, a fact that causes some queries. In tables $V I-I X$ we can see that most of the Enterococci strains (figure $1 c-e$ ) - a total of 9 have diameters ranging between 0.87 and $1.01 \mu \mathrm{m}$ while the other three have more or less the same diameters. The Streptococcus faecalis cells (known now as Enterococcus faecalis), as described by Mundt [14], are 0.5 to $1.0 \mu \mathrm{m}$ in diameter which is more or less similar to what we found.

A look at the statistics of the cocci genera can persuade us that the results are quite acceptable. The standard deviation, which is an indication of great importance for the accuracy of the results, is low or around $10 \%$ of the mean value. This percentage might be decreased by increasing the number of measurements; however, $10 \%$ is quite acceptable for the statistical method of ANOVA described below.

As far as the twelve Lactobacillus delbrueckii subsp bulgaricus strains are concerned (figure 2), we cannot make any deductions concerning their width and length (data not shown). The width varies between 0.7 and $1.00 \mu \mathrm{m}$ with more than half of the strains above $0.88 \mu \mathrm{m}$. Great differences are found in the length of the cells. This can be partly explained with the fact that, with a few exceptions, young cells are much longer than old or mature ones. Knaysi [10] showed that cells of B. subtilis from a 4-h culture measured from five to seven times the length of cells from a 24-h culture. Variations in width are much less pronounced. A decrease in cell length and width appears to be due to a variety of factors. The major causes appear to be changes in the environment with the accumulation of waste products. An increase in the osmotic pressure of the medium will also cause a decrease in cell size and may possibly be the most important factor [18].

It is worth mentioning that it was impossible to measure the length of many cells due to their curved shape. Additionally, the cell edges were, in many cases, difficult to 
Table IX. Classification into groups of the Enterococci strains according to the mean of their cell diameter. Tableau IX. Classification des souches d'Enterococci en groupes suivant leur diamètre cellulaire moyen.

\begin{tabular}{lc}
\hline Groups (in $\mu \mathrm{m}$ ) & Strains \\
\hline $0.8-0.87$ & 138,225 \\
$0.87-0.94$ & $239,240,165,241,242,223,226$ \\
$0.94-1.01$ & 174,228 \\
$1.01-1.08$ & - \\
$1.08-1.15$ & 252 \\
\hline
\end{tabular}

Table X. ANOVA table.

Tableau X. Résultats de l'ANOVA.

\begin{tabular}{lcccc}
\hline Source & Sum of squares & d.f. & Mean square & F-ratio \\
\hline Between groups & SSA $=0.598$ & 2 & MSA $=0.299$ & 38.33 \\
Within groups & SSE $=0.260$ & 33 & MSE $=0.0078$ & \\
Total & SST $=0.858$ & 35 & & \\
\hline
\end{tabular}

Figure 2. Picture of a lactobacilli strain as received from SEM.

Figure 2. Photographie d'une souche de lactobacille obtenue par MEB.

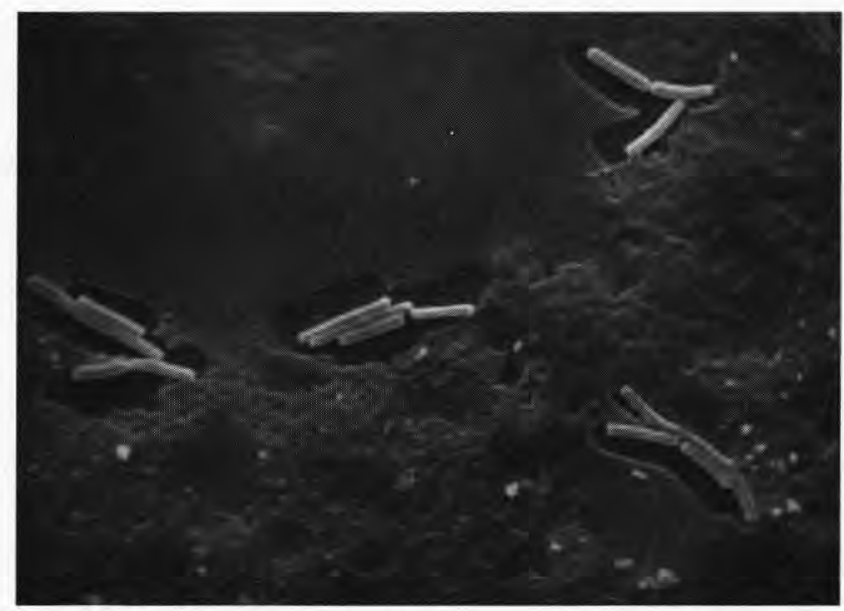

distinguish and therefore measurement was impossible. For those with a straight cell and clearly visible, their length varied considerably between $2.8 \mu \mathrm{m}$ and $5.35 \mu \mathrm{m}$. As far as we know the Lactobacillus delbrueckii cells are 0.5 to $0.8 \mu \mathrm{m}$ in width and 2 to $9 \mu \mathrm{m}$ in length [9], which is quite similar to our results. Moreover, it was not possible to find any relationship between the widths and the lengths of each strain despite the fact that all the culture conditions were the same for all strains. This should be considered for further research.

By comparing the data of the three cocci genera, it becomes evident that there is a significant difference in the size of their cells. The Streptococcus thermophilus strains seem to be the biggest, with the Ente- 
rococci strains being smaller, whereas those of the Lactococcus lactis subsp lactis being the smallest. This was also verified by applying the ANOVA (analysis of variance) statistical method to the mean values of the sizes of the different strains of each different genus. Our aim was to find any statistically significant differences of the mean values of the cell diameter of the three cocci genera at the $5 \%$ level of significance. The features of the analysis of variance are shown on table $X$. Since $F_{2}, 33 ; 0.05=3.3$ and $\mathrm{F}=38.33>3.3=\mathrm{F}_{2,33 ; 0.05}$, we can safely say that there is a significant difference between the diameter of the three cocci genera. This also supports the impression we had when examining these genera with the light microscope or analyzing the results with the image analysis.

The application of this work in numerous different strains from different genera, could give us the ability to create a database containing their cell sizes, which would be a very useful data for the numerical taxonomy of bacteria. Consequently, the cell size in addition to the classic methods can provide us with a more precise identification and classification of an unknown strain, and that is of great importance.

\section{ACKNOWLEDGMENTS}

We thank E. Manolopoulou in charge of the ACA-DC Collection and I. Psarokostopoulos for technical assistance with the SEM.

\section{REFERENCES}

[1] Bottazzi V., Bianchi F., I Microorganismi Lattiero-Caseari al Microscopio Elettronico a Scansione, Edi-Ermes, Milan, Italy, 1984.

[2] Bottazzi V., Battistoti B., Bianchi F., MicrocoIonies of thermophilic lactic acid bacteria in Grana cheese, Microbiol. Aliment. Nutr. 1 (1983) 285-291.

[3] Bryant A., Ustunol Z., Steffe J., Texture of Cheddar cheese as influenced by fat reduction, J. Food Sci. 60 (1995) 1216-1219, 1236.

[4] Hardie J, Genus Streptococcus, in: Bergey's Manual of Systematic Bacteriology Vol. 2, The Williams and Wilkins Company, Baltimore, MD, USA, 1986.
[5] Herald P.T., Zottola E.A., Scanning electron microscopic examination of Yersinia enterocolytica attached to stainless steel at selected temperatures and $\mathrm{pH}$ values, J. Gen. Microbiol. 137 (1988) 549-559.

[6] Hood S.K., Zottola E.A., Electron microscopy study of the adherence properties of Lactobacillus acidophillus, J. Food Sci. 52 (1987) $791-792,805$.

[7] Joyce-Loebl Ltd., Image Analysis: Principles and Practice. Joyce-Loebl Ltd., Gateshead. England, 1989.

[8] Kalàb M., Allan-Wojtzas P., Shea Miller S., Microscopy and other imaging techniques in food structure analysis. Trends Food Sci. Technol. 6 (1995) 177-217.

[9] Kandler O., Weiss N., List of the species of the genus Lactobacillus, in: Bergey's Manual of Systematic Bacteriology Vol. 2, The Williams and Wilkins Company, Baltimore, MD, USA, 1986.

[10] Knaysi G., Cytology of bacteria, Botan. Rev, 4 (1938) 83.

[11] Lagoueyete N., Lablée J., Lagaude A., Tarodo de la Fuente B., Temperature affects microstructure of renneted milk gel, J. Food Sci. 59 (1994) 956-959.

[12] Lortal S., Rousseau M., Boyaval P., Van Hieijenoort J., Cell wall and autolytic system of Lactobacillus helveticus ATCC 12046, J. Gen. Microbiol. 137 (1991) 549-559.

[13] McManus W.R., MeMahon D.J., Oberg C.J., High resolution scanning electron microscopy of milk products: a new sample preparation procedure. Food Struct. 12 (1993) 475-482.

[14] Mundt O.J., Enterococci. in: Bergey's Manual of Systematic Bacteriology Vol. 2, The Williams and Wilkins Company, Baltimore. MD. USA, $1986 a$.

[15] Mundt O.J., Lactic acid Streptococci. in: Bergey's Manual of Systematic Bacteriology Vol. 2, The Williams and Wilkins Company, Baltimore, MD, USA, 1986b.

[16] Prescot L., Harley J., Klein D., Microbial taxonomy, in: Microbiology, 2nd Ed, William C. Brown Communications, Inc, Dubuque, Iowa, USA, 1993.

[17] Rousseau M., Study of the surface flora of traditional Camembert cheese by scanning electron microscopy, Milchwissenschaft 39 (1984) 129-135.

[18] Salle J., Fundamental Principles of Bacteriology, 3rd Ed., McGraw-Hill, New York, USA. 1948.

[19] Zani G., Severi A., Cellular ultrastructure and morphology in Bifidobacterium bifidum, Microbiologica 5 (1982) 255-267.

[20] Zenseky Y., Tokunaga J., Tawara J., Atlas of Scanning Electron Microscopy in Microbiology, Georg Thieme Publishers, Stuttgart, Igaku Shoin Lid., Tokyo, 1976. 